\title{
An Advocacy of English Posters Use in Kindergarten Classrooms as the Teaching Strategy
}

\author{
Kurniawati, Universitas Airlangga
}

\begin{abstract}
The walls in kindergarten classroom are mostly filled with colorful visual aids, whether it is a printed poster or students' drawing. This study aims to observe the suitability of the teaching strategy towards the students to what extent the colors and pictures contribute to students' learning interest. The theory from Kress and Leeuwen (1996) is used to observe the influence of semiotic resources composition in kindergarten visual aids towards students' learning. Taking some photographs are used as the method of data collection. The data was collected randomly from Pelita Jaya School Bilingual Kindergarten in Surabaya which has long been applying English as one of the subjects in the curriculum. Descriptive method is used to elaborating the data. The finding of this study perceives the advocacy of suitability by using English text for kindergarten students' learning process in their learning tools. This study is expected to contribute to the use of materials that can assist the kindergarten students' English learning process and to reveal the important of pictures as the essential media in teaching and learning process in kindergarten students.
\end{abstract}

Keywords: advocacy; english text; multimodal; semiotic; suitability, teaching strategy; visual tools

\section{Introduction}

Teaching English will be something that can be very difficult, especially in a country that does not speak English as a first language or a second language. The way of delivering the material and the development of experts in the history of teaching and learning world. It is intended to be effective and maximal learning outcomes for students in mastering English. In this case, for every level of education, the selection of learning systems and instructional media also needs to be taken into account and prepared.

The world of children deals with fun and eye-catching things; such as colored walls, toys, bookshelves, displays of works, pictures on the walls. They represent what can draw attention to learning and attention, fun to do, and not boring. All the corner classrooms will be decorated with colorful ornaments and fun trinkets. Not to mention the work of drawings and writings on the wall. When combined with an interesting topic it is that it will be the right combination to teach children.

Masitoh in Siti Aisyah, et al (2008: 13) suggests learning activities in kindergarten prioritize playing while learning and learning while playing. The most effective learning for kindergarten children is through a concrete activity with play orientation. In his interpretation, combining fun learning media is more effective, such as a picture. Instruction with the principle of learning in kindergarten is "Play While Learning", learning English introduction in Kindergarten should also be presented with play, fun, and use the media of interest.

Being an assumption when a foreign language is taught early on will provide convenience because children have imitative properties. More than that, it has become a common knowledge that in the learning system, especially at the level of kindergarten learning media has developed and varied. Therefore it takes a very creative thinking in shaping the character of the linguistic of children. For example, using drawing media, which is one of the creative activities in the curriculum of character formation of students. In practice and will be the question, how far is the role of media in the formation of child language characters? How important is the role of an image for the cognitive of the children of the masterpiece of language, especially English which is not the 
mother tongue or the second language of a learner? Beyond its function as a medium of communication, children can use language as a means of developing thinking skills. The thinking ability of this child will be developed, if in the learning used media images. These image media can be photos, graphs, charts or diagrams, and posters. The existence of media images will certainly stimulate the interest of children with media. This sense of interest will encourage their thinking skills.

\section{Literature Review}

Teachers are a fundamentally very important influence in implementing teaching strategies. According to the results of research by Slamet (2015) proceeded article entitled Model Learning English at Kindergarten Widyapura Pajang, Surakarta. In practice, using two languages (bilingual) will greatly help students understand their cognitive aspects. Basically, the teacher only needs to provide feedback, questions in English but translated into Indonesian, and using the opening pattern, initial apperception, core, evaluation, and closing.

On the other hand, effective learning media presented through the results of his research in a journal article entitled Utilization of Media in Social Knowledge Lesson in Kindergarten (2014) to prove the existence of media image attachment with the reality of thinking children. Because children tend to believe what's on their minds. Cognitive children will be greatly honed with the help of the media is a model that serves as a messenger message of the abstract element into a concrete element that can be seen and felt. The teacher plays a role in becoming a language entity.

Added from Supriyanti's research (2016) in his journal article entitled Improvement of Language Capability through Media Picture of Child of BII Group of PKK Tunas Kartini Moyu dan Sleman Yogyakarta, mentions that the role of image media in the form of the card can help students in reading comprehension ability. Students' reading ability from before action until after the class action has achieved $75 \%$ success. This shows the role of image media that significantly stimulates students to focus more and focus on one concrete object. The activity of students has increased because of interest in the object of an interesting image.

\subsection{Pedagogical Text and the Significance}

In practice, the wall is a vast vehicle that is around the children to be used as a place to attach images and writings from students. It's role as a pedagogical text that indirectly accommodates or documenting all the creative cognitive activities of the students over a particular concept that is in line with the National Framework Plan for Content and Tasks of Kindergartens (2006) 1 in Granly (2012) et al indicates that the importance of general documentation of activities and the texts on the walls of the assistance of claims for pedagogical documentation. Images and writings are made of the communication media shown by students because of the mastery and understanding of certain concepts. It is a matter of pride if students can demonstrate the achievement of new knowledge. Can be studied together, the cognitive activities of students during teaching and learning activities. If arranged in one framework, theme and certain topic then will be realized learning concept that can form cognitive student. Furthermore, the roles of teachers and students to be students and introductory students on achievement from students. Students are granted to connect to the entity and how to embody the language entity into a new vocabulary in English. From this stage students can finally be aroused and directed to a concept that can be used in the context of the use of the language of reading, listening and speaking.

\subsubsection{Visual Literacy}

Multimodality has long been used to investigate the use of visual tools (poster, photograph, color, etc.) and language. In his understanding, the combination of differentsemiotic modes - for example, language and music - in a communicative artifact or event. (Leeuwen, 2005: 28). In this case, multimodal as an underlying theory and practical approach to visual communication is used as part of the learning outcomes of English. Apart from media literacy and textual literacy, visual 
literacy is the appropriate approach of this study. Based on Anthony Pennings in Liu (2013) Visual literacy is an emerging area of study which deals with what can be seen and how we interpret what is seen. The idea is to use the visual aspect to communicate an idea or concept. The idea is to use the visual aspect to communicate an idea or concept. Further, Liu (2013) asserts that visual images may involve body language, motion, dance, two and three-dimensional works of art, photographs and clip arts, films and videos, museum exhibits and dioramas, advertisements, illustrated written or verbal discourse, hypermedia and visual reality experiences, and so on. Thus, the use of art components will be the main point in this kind of communication. The role of semiotics is really essential as the sharp blade to execute the data. Semiotic will evaluate the use of the art component including the color choice, shape, symbol and the use or certain ornament in the picture.

\subsubsection{Referentiality}

According to what can be interpreted from Kress and Van Leeuwen $(1996,2006)$ that image, color, music, typography and other visual modes are similar to language and they can simultaneously fulfill and realize the three broad communicative metafunctions as language does, this shows that the visual tool can provide new communication options for children. That way the learning system and strategies can develop and facilitate students' understanding that is assisted by visual aids that dynamically adjust the learning needs contextually.

As a way to understand the concept of a "thing" visually, we will deal with semiotic. The concept of naming in semiotic was proposed by Lewis (1990: 139), he stated "When we name things, we call them into being. We permit them to enter our consciousness but only in the garb in which we have dressed them. "We use a term refers to an entity. In this point, we perceive knowledge about an entity get along with the characteristic, and the features. Moreover, the same thing method of learning will get the students into the same perspective about a "thing". Visually, children will be conducted to the process of "making meaning" which every object, sign, symbol, colors, and its combination with words refer to a "thing" that has a meaning that universally understand.

\section{Research Method}

This research uses a descriptive method. According to Nawawi (2012: 67) "Descriptive method can be interpreted as a problem-solving procedure investigated by describing/illustrating the state of subjects/research objects (someone, institutions, society, and others) at the present moment based on visible facts, or as existence ". In other words, the data will be described based on the theory in order to reveal the significance of the issues.

Randomly collected data collected from one of the kindergarten school in Surabaya city which apply two languages (bilingual) in the learning process. The data collected in the form of photos made by playgroups and kindergarten students in Pelita Jaya School Bilingual Kindergarten. After that, the data will be described by the significance. Semiotic works on the description of the color, writing, and image functions that exist on the (visual tool) created by students.

\section{Discussion}

After collecting the data, randomly is selected three photographs. Photograph 1 in the form of "Wall Magazine" made of yellow cloth and ornamental decoration. The decorative object is a cut, a boy and a girl, a train, an elder sister, grass and various patches. "Wall Magazine" is a kind of wall magazine where affixing students' work. The tools are placed on the classroom wall and the best spots that can be seen widely and freely by students and other school members. This means of communication is considered very powerful for students to show what has been done on teaching and learning activities. This can motivate the students. Visually, this "Wall Magazine" has a bright color that is yellow in the background. It is intended that this tool can be easily captured by the eye. 
As can be seen in Picture. 1 below, the ornaments affixed to "Wall Magazine" are closely related with children and their work.

\section{Picture 1}

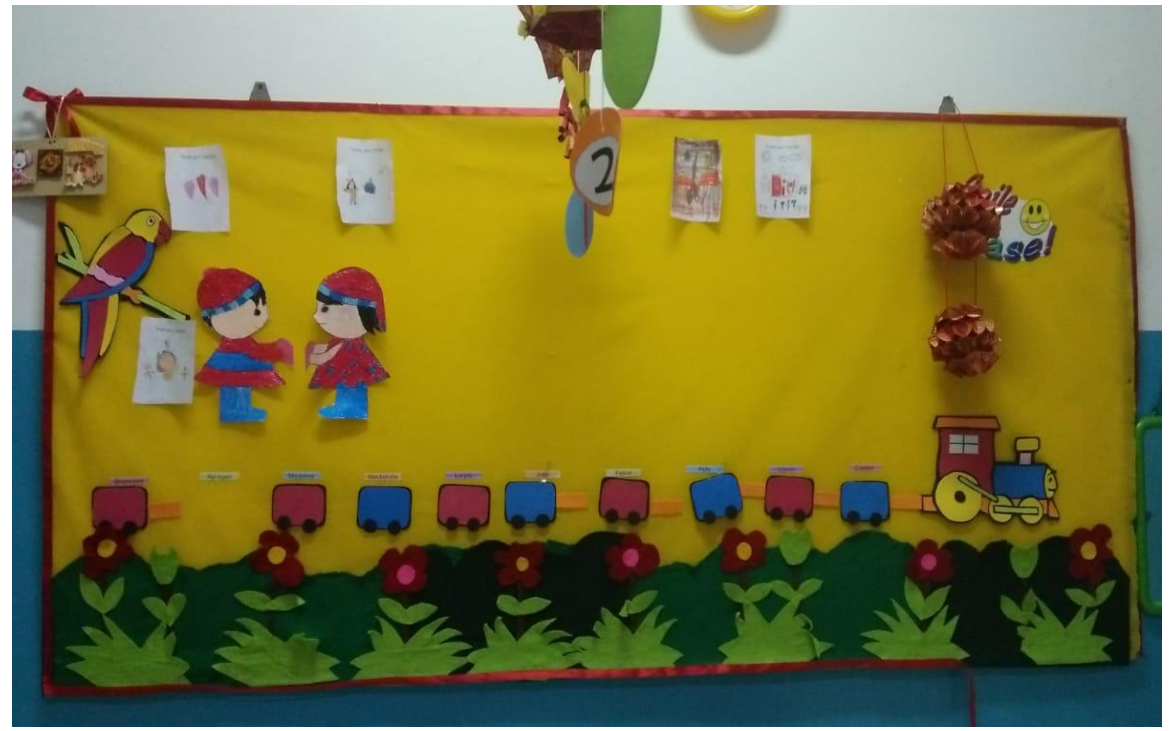

In the Picture 2 below, it can be seen that two pictures attached, each picture is labeled "smiley with the thumbs up" yellow. In addition to the label, there are two different activities seen the first time the activities performed by a small girl is throwing garbage in the trash. This activity is recorded onto a blue background paper. Meanwhile, the next picture of this activity is a boy who is smoothing his toys on a basket. Based (https://www.merriam-webster.com/dictionary/thumbs-up) "thumbs up" is an example or attitude of approval or encouragement. This phrase can be used literally or figuratively. Meanwhile, Smiley (https://www.merriam-webster.com/dictionary/smiley) is smiling: smiling often smiling children. Universally, the "smiling with thumbs up" icon is an expression of approving good things and good value.

\section{Picture 2}

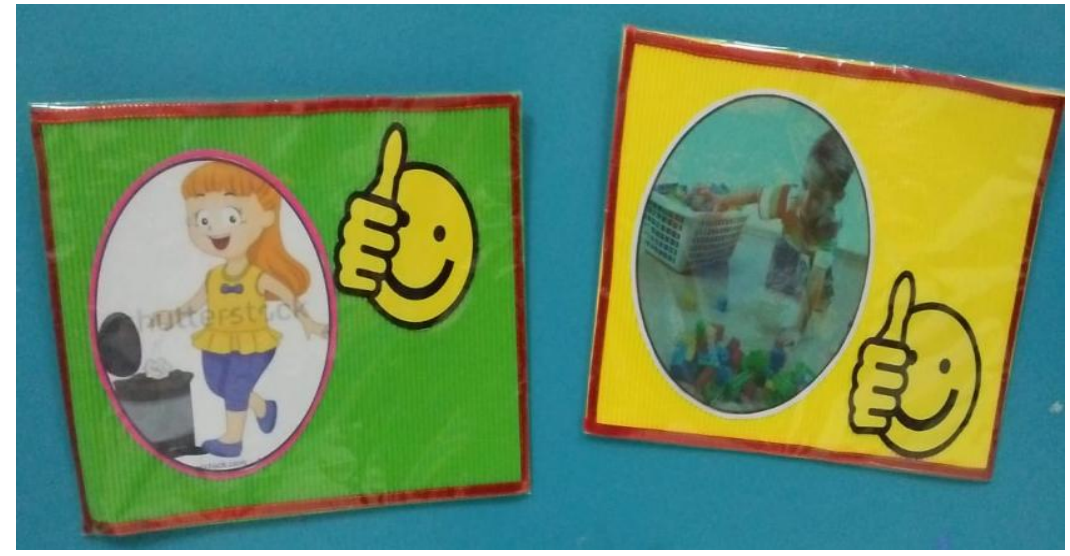

Culturally, these two activities are labeled "smiley with the thumbs up" which means good things. It means, what these children do was good things. Children should be taught good manner and doing goods. Good things should be taught at this early age while the student is still in kindergarten. Socially and universally, the public understands the need to teach their children 
positive and good things. This would be a good habit. There is a positive value of discipline and values that school is trying to plant.

While, in the last picture, provide us with the thematic picture that related to the season. In this point, the language also takes control. There is a combination of picture, symbol, sign, colors, and language. Picture. 3 as follows, is one of the representatives of the students. There is a spring that can be recognized by a tree and pink flowers on it. Surely, labeled by the word spring. Followed by summer with the sun and a tree with no flowers on it. The third season is fall which can be viewed by the orange maple leaves fall down on the ground, and the last season is falling with snow covers up the tree and the ground.

\section{Picture 3}

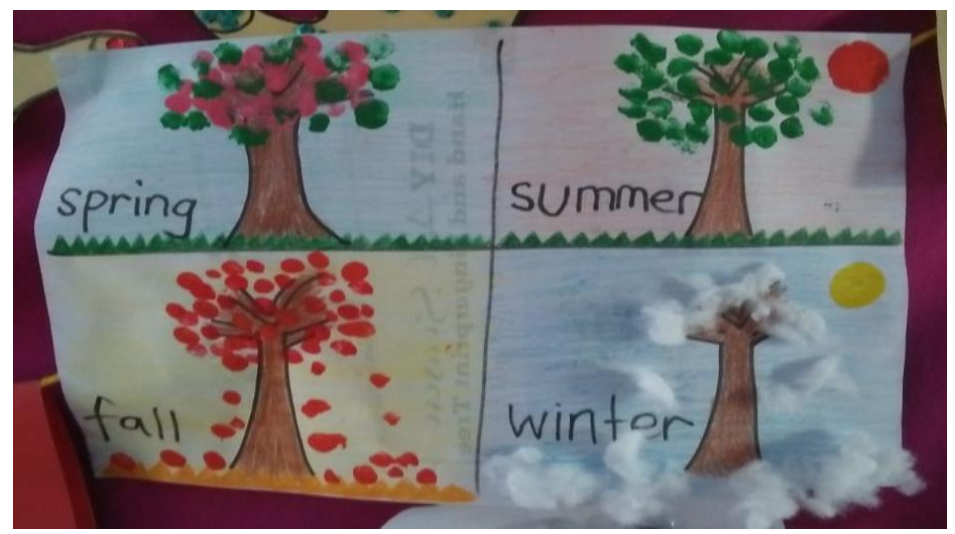

In Picture. 3, there is a process of "naming", when the signifier is the word of "spring", "summer", "fall", and "winter" while the signified is the image of a tree and the sign of the seasons. Surely, in our mind, the idea of the season is led by the image of seasons. The entity of the season and words are presented by the pictures. This process will be formed in the student's mind since the picture motivates them to recognize the season by its characteristics.

\section{Conclusion}

The picture is one of the important tools that can help the learning process that serves to clarify the meaning of the message delivered so that the goal of teaching can be achieved better, more perfect. Learning media have an important role in learning English in kindergarten. Many media can be brought into the classroom which can stimulate students to learn. One of the media that can be used for learning is the media images. Furthermore, the means used is the wall media as an appreciation point. After going through the learning process students can pour concepts obtained by using images. Activities that can be done are drawing, coloring pictures, and give pieces of pictures.

Pictures as visual tools can be a means that stimulate student creativity. From a simple drawing, the student can write down what appears in the picture. Even a student could write other things besides the ones on the picture. In using the image media, students should be encouraged to explore existing media. That way, students can appreciate and express themselves. We should not stop the process until at this point but rather provide monitoring and mentoring as a motivation to the students and provide insight that the knowledge already learned can be used as additional knowledge in daily communication. 
The development of the theory of cognitivism which believes that not only the role of the environment alone influences the development of language. However, continuous interaction with the language environment will train the cognitive maturity of a learner (Chomsky in Izzak, 2006: 45). Therefore it is necessary to combine learning, in addition to using verbal and non-verbal media (text), learning can use the image media combined with text (multimodal). Image media plays a role in the cognitive maturity of children in obtaining language both naturally and in classroom learning.

\section{Reference}

Merriam-Webster Dictionary: America's most-trusted online dictionary. Available at https://www.merriam-webster.com/dictionary/smiley. (Accessed 14 June 2018)

Merriam-Webster Dictionary: America's most-trusted online dictionary. Available at https://www.merriam-webster.com/dictionary/thumbs-up. (Accessed 14 June 2018)

Granly, Astrid et al., 2012. Multimodal texts in kindergarten rooms. Education Inquiry. Vol. 3 (3). 371-386.

Hendarwati, Endah. 2014. Pemanfaatan Media Dalam Pembelajaran Pengetahuan Sosial Di Taman Kanak-Kanak. Jurnal Pedagogi, 1(1).

IIzzak, Arif. 2004. Fungsi Ingatan Bahasa pada Proses Pemerolehan BI Anak-anak. Jurnal Medan Bahasa. (3). 459-479

Lewis, D. (1990). The constructedness of texts: Picture books and the metafictive. Signal: Approaches to Children's Books, (62)139.

Liu, Jing. 2013. Visual Images Interpretive Strategies in Multimodal Texts. Journal of Language Teaching and Research, Vol. 4 (6). 1259-1263

Nawawi, Hadari. 2012. Metode Penelitian Bidang Sosial. Yogyakarta: Gajah Mada Universitas Press.

Slamet, S. 2015. Model Pembelajaran Bahasa Inggris Pada Taman Kanak-Kanak Widyapura Pajang, Surakarta. 316-322.

Supriyanti. 2016. Peningkatan Kemampuan Berbahasa Melalui Media Gambar Anak Kelompok BI Di TK PKK Tunas Kartini Moyu dan Sleman Yogyakarta. Jurnal Pendidikan Anak, Vol.5 Edisi 2

Van Leeuwen, T. 2005. Introducing Social Semiotics. London: Routledge. 